\title{
Evaluation of the interference of oral tolerance in the rejection of avascular allogeneic heart grafts to mouse ears
}

\author{
Avaliação da interferência da tolerância oral na rejeição do transplante de coração alogênico avascular \\ na orelha de camundongo
}

Alberto VALENCIA ${ }^{1}$, Eduardo Sérgio BASTOS² ${ }^{2}$ Vinicius da CONCEIÇÃO ${ }^{3}$, Sylvia Maria da Nicolau CAMPOS ${ }^{4}$, Isabela di Puglia CARVALHO ${ }^{5}$, Kalil $\mathrm{MADI}^{6}$, Gerlinde TEIXEIRA ${ }^{7}$

RBCCV 44205-798

\section{Abstract}

Objective: Although the development of surgical techniques and the discovery of immune-suppressors permitted heart transplantation to be accepted as a widespread treatment for terminally ill patients, rejection, complications due to these drugs and the chronic vasculopathies continue to be majority problems. The search for alternatives to supplant these impediments by performing avascular allogeneic heart transplants from newborn BALB/C mice (24h old) to the subcutaneous tissue of the ears of adult male $\mathrm{C} 57 \mathrm{BI} / 6 \mathrm{~J}$ and C3H/HEJ mice to evaluate the interference of systemic oral tolerance on the rejection mechanisms are our main goal.

Method: Adult, male C57BI/6 and C3H/HEJ were divided in two groups. The tolerant group received peanuts ad libitum for 1 week in the diet while the immune group continued to eat mouse chow. Both groups were immunized sc with $100 \mathrm{mg}$ of peanut extract. The transplanted newborn BALB/ $C$ hearts were deposited into the subcutaneous tissue of the ears of tolerant and immune mice in the presence or not of concomitant immunization to peanut protein.

Results: We demonstrated that feeding proteins induces systemic tolerance since animals of both strains that ate the seeds before being immunized had lower systemic antibodies than immune animals. Tolerant $\mathrm{C} 3 \mathrm{H} / \mathrm{HEJ}$ mice with concomitant administration of the tolerogenic antigen presented a more preserved transplanted heart than all other groups.

Conclusion: Although not homogeneously, the immunoregulatory mechanisms of oral tolerance modified the rejection process of allogeneic avascular heart transplants to the ear of adult mice. As these mechanisms are not yet well understood more work needs to be done in this field.

Descriptors: Immune tolerance. Transplantation, heart. Graft rejection. Mice.

1 - Physician (post graduation student in the General Surgery Department

- Heart Surgery Sector of the Universidade Federal do Rio de Janeiro).

2 - Cardiovascular Surgeon (Professor da Universidade Federal do Rio

de Janeiro).

3 - Student

4 - Nutritionist (Professor of the Universidade Federal Fluminense).

5 - Physician (Cardiology post graduation student of the Universidade

Federal Fluminense).

6 - Pathologist (Adjunct Professor of the Universidade Federal do Rio de Janeiro).

7 - PhD (Adjunct Professor of the Universidade Federal do Rio de Janeiro).

Work performed in the Universidade Federal do Rio de Janeiro (UFRJ). Correspondence address: Alberto Valencia. Av. Brigadeiro Trompowski, $\mathrm{s} / \mathrm{n}^{\circ}$, Prédio da Reitoria, $2^{\circ}$ andar - Cidade Universitária. Rio de Janeiro, RJ - CEP 21941-590.

E-mail: valencia@cardiol.br 


\section{Resumo}

Objetivo: Apesar da evolução das técnicas cirúrgicas que permitiram a padronização do transplante cardíaco e da descoberta dos imunossupressores, ainda hoje, a rejeição, os efeitos colaterais dos medicamentos e o processo de vasculopatia crônica são os principais problemas nos póstransplantados. A procura por alternativas para superar estes impedimentos é o objetivo principal deste trabalho. Assim, foram realizados experimentos para determinar se a tolerância oral pode interferir no transplante cardíaco.

Método: Camundongos C57BI/6J e C3H/HEJ, machos adultos foram divididos em dois grupos. $\mathrm{O}$ grupo denominado tolerante recebeu amendoim ad libitum na dieta por sete dias, enquanto o grupo imune foi mantido com uma dieta convencional para murinos. Ambos foram imunizados com $100 \mathrm{mg}$ de extrato protéico derivado do amendoim por via sc. $O$ transplante de coração de BAL/C recém-nato, de $24 \mathrm{~h}$, foi depositado no tecido subcutâneo das orelhas dos animais de ambos os grupos, com ou sem imunização concomitante do antígeno alimentar.

Resultados: Confirmamos que a administração de proteínas

\section{INTRODUCTION}

One of the most significant achievements in modern medicine has been heart transplantation, starting with animal experiments in the first years of the 20th century to the orthodox treatment accepted for a great variety of patients with terminal heart diseases that we see today. The first published report of organ transplantation was presented by Carrel and Guthrie [1] in 1905, when the heart of a puppy was transplanted into the neck of a larger dog. In December 1967, Dr. Christian Barnard [2], who had spent some time with Lower in Virginia observing orthotopic heart transplantation, performed the first heart transplantation between human beings, in Cape Town, South Africa. After five months, in May 1968, the first heart transplantation in Brazil was performed by Dr. Zerbini [3].

After a period of enthusiasm caused by the discovery of the technique, the situation became obscure due to the insurmountable problems of heart rejection and the programs were temporarily suspended. The pre-cyclosporine changes were initially described by Billingham in 1974, who developed a histological classification system of rejection por via oral é capaz de induzir tolerância sistêmica, uma vez que os grupos tolerantes apresentam títulos de anticorpos específicos ao amendoim mais baixos que os grupos imunes. $O$ coração transplantado apresentou-se mais preservado no grupo de animais $\mathrm{C} 3 \mathrm{H} / \mathrm{HEJ}$ tolerantes que foram desafiados concomitantemente com o antígeno da dieta do que os demais grupos.

Conclusão: Foi determinado que os mecanismos de tolerância oral interferem no processo de rejeição de transplantes cardíacos alogênicos avasculares para a orelha de camundongos adultos, no entanto, de maneira não homogênea. Como os mecanismos de tolerância oral que alteram o sistema imunológico de modo a reduzir a rejeição ainda não foram esclarecidos, são precisos mais trabalhos nesta linha de pesquisa.

Descritores: Tolerância imunológica. Transplante, coração. Rejeição de enxerto. Camundongos. based on endomyocardial biopsies [4].

Although infection and rejection are the greatest causes of failure in transplanted patients, pathological alterations such as ischemia, interstitial fibrosis, myocardial calcification, endomyocardial infiltrates, myocyte hypertrophy and chronic coronary artery disease are significant complications in the survival of the graft. Among them, the last is the greatest threat [5].

During the rejection process, the presence of the $\mathrm{T}$ and B lymphocytes is important. These regulate the secretion of the molecular components that intermediate inflammation responsible for rejection [6]. In spite of the notable presence of cytotoxic T cells in an allograft, the TCD4+ cells are the ones responsible for initiating and organizing the immune response to this process [7].

In the rejection mechanism of transplantation, the neuralgic part of the process is the recognition of new cells of the Major Histocompatibility Complex (MHC) that are the most polymorphic molecules registered. For humans, we can utilize the general nomenclature (MHC) or Human Leukocyte Antigen (HLA) specific nomenclature. From this genic complex, two groups of proteins appear that 
are directly involved in the cellular recognition process between lymphocytes and the organism's cells, Class I and II molecules [8].

As the complexity of the immunological system and the mechanisms of rejection become known, it is possible to investigate ways and strategies that can block rejection. Clinically, medicines with immunosuppressing elements are widely used. Cyclosporine A and FK506 block the activation of cytokines such as IL-2, while azatioprine and cyclophosphamide inhibit the growth of lymphocytes. Sirolimus (rapamycin) blocks the growth of T-cells in response to IL-2. Another widely used medicine is glycocorticoid that acts on T-cells, activating endonuclease that cleaves the DNA, leading to death by apoptosis. The newest immunosuppressing medicines such as, for example, FK-506 (tacrolimus) is promising, as they increase the immunosuppression but have fewer side effects [9].

Treatment with antibodies against $\mathrm{T}$-cell receptors (TCR), administered before transplantation is one among several strategies to block rejection [10]. This produces a state of hyporesponsivity to cardiac allografts with the intra-graft reduction of Th1-type cytokines (IL-2 and IFN- $\gamma$ ) and a consequent increase in Th2-type cytokines. The longest survival is associated to the inhibition of the Th1-inducing pro-inflammatory activity. Treatment with anti-CD3 antibodies or anti-CD4 antibodies, in particular, prolongs allograft survival, as it reduces the T-lymphocyte population, inhibiting infiltration in the graft [11-13].

Another very promising manner to block rejection in transplantation is to utilize strategies that try to modulate molecules in the microenvironment to which the effector lymphocytes migrate. Anti-laminin treatment in cardiac allografts in mice has caused a reduction in the accumulation of lymphocytes in lymph nodes, as well as in the transplanted heart [14], even in avascular allogeneic heart transplantations in mice [15].

Ehrlich [16] in 1900 demonstrated that the immunological system does not react to its own constituents but it is able to react to foreign elements. And so, it was necessary to explain the fact that under normal conditions the immunological system does not cause auto-aggression leading to diseases, while it is able to react to what comes from outside.

On the contrary to what is normally thought, the greatest surface in contact with the world outside is not the skin, but mucosa, including the digestive tract, that presents an area around 300 to 600 times greater than the skin [17]. This entrance represents the greatest source of disorders to the immunological activity in the organism. However, in the majority of cases, penetration by antigens in this way does not determine the classically expected immunological responses, on the contrary, it causes a phenomenon named "oral tolerance".

Although not recognized, oral tolerance was the first immunological based phenomenon to appear in the literature reported by Jenner in 1798, in respect to antivariolic vaccination. Although it has been described several times since the start of the 19th century for different proteins including the proteins of the milk, corn and egg, the phenomenon of oral tolerance has been systematically forgotten or neglected.

Part of the ingested macromolecules is absorbed by mucosa, entering in direct contact with the intra-epithelial lymphocytes and the Peyer plaques [18]. The rapid absorption of intact macromolecules into the circulation can be evidenced both by laboratorial methods and clinically, where food allergies lead to generalized manifestations in seconds or minutes after the ingestion of allergenic foods. There is evidence that the organism is also immunized to infectious agents through the mucosa, such as, for example, to the poliomyelitis virus, in which oral vaccination has proved efficacious [19].

Considering the facts reported, might it be possible to perform heart transplantations free of immunosuppressing drugs by using the oral tolerance mechanism? We knew the road would be long, but we could start with one small step and so, we thought about using an experimental model of heart implantation in mice, according to the model proposed by Fulmer et al. [20], a feasible technique that does not require great sophistication [21]. Thus, the general goal was to induce oral tolerance and to perform the transplantation, with and without concomitant stimulation of the antigen for which toleration was induced and verify if the indirect effects of oral tolerance hinder or delay rejection of allogeneic heart transplantations.

\section{METHOD}

\section{Animals}

Isogenic mice, bred and housed in the Nucleus of Laboratory Animals, in the Federal Fluminense University (FFU), with feed and water ad libitum, were utilized. The recipients were adult male animals of 6-8 weeks old, from the $\mathrm{C} 3 \mathrm{H} / \mathrm{HEJ}$ and $\mathrm{C} 57 \mathrm{Bl} / 6 \mathrm{~J}$ lineages and the donors were new-born BALB/C mice of up to 24 hours of life.

Each lineage of mice was divided into 4 subgroups (Table 1) with 5 in each group $(20 \mathrm{C} 3 \mathrm{H} / \mathrm{HEJ}$ and $20 \mathrm{C} 57 \mathrm{Bl} / 6 \mathrm{~J})$. Handling of the animals and immunochemical manipulation were performed in the laboratory of Gastrointestinal Immunology of the Immunobiology Department in FFU. The histological techniques were performed in the Department of Pathology of the Federal University in Rio de Janeiro.

\section{Peanut Proteins}

Proteins were extracted according with the methodology developed for the extraction of peanut proteins [19].

In brief, the peeled seeds were ground in an electric 
Table 1. Experimental protocol for immunization and tolerance both for $\mathrm{C} 3 \mathrm{H} / \mathrm{HEJ}$ and $\mathrm{C} 57 \mathrm{Bl} / 6 \mathrm{~J}$ mice

\begin{tabular}{lcccc}
\hline & 7-Day & D Day & 28 Day & Day \\
& Tolerant Diet & Primary Immunization & Secondary Immunization & Challenge \\
\hline Tolerant & Peanut & Peanut $+\mathrm{Al}(\mathrm{OH}) 3$ & Peanut & Peanut + transplantation \\
Immune & Animal feed & Peanut $+\mathrm{Al}(\mathrm{OH}) 3$ & Peanut & Peanut + transplantation \\
Normal + & Animal feed & Saline & Saline & Peanut + transplantation \\
Normal - & Animal feed & Saline & Saline & Transplantation \\
\hline
\end{tabular}

coffee-type grinder. The resulting material was placed in a $15 \mathrm{~mL}$ tube and suspended in an extraction buffer $(\mathrm{pH} 9.7$ borate buffer) at a proportion of 1:10 p/v, under inversion stirring for 30 minutes at room temperature. After this, the material was centrifuged at $5^{\circ} \mathrm{C}$ at $3000 \mathrm{rpm}$ for 30 minutes and any floating material was removed. The concentration of proteins was determined by the technique described by Lowrey et al. [22].

\section{Oral tolerance induction with seeds}

The animals received peanuts together with the animal feed, for a period of from 7 to 10 days.

\section{Immunization with unrefined peanut extracts}

In primary immunization, each animal received $100 \mu \mathrm{g}$ of the peanut protein plus $1 \mathrm{mg}$ of $\mathrm{Al}(\mathrm{OH})_{3}$ (adjuvant) at a final volume of $200 \mu \mathrm{L}$ by subcutaneous injection in the dorsum. After 21-28 days, the animals received an equally administered second immunization without the adjuvant.

\section{Blood withdrawal}

Blood samples of $200 \mu \mathrm{L}$ were withdrawn from the retroorbital plexus after 7 days of exposure to the antigens. The blood was diluted to $10 \% \mathrm{v} / \mathrm{v}$ in saline solution. After the removal of blood clots the blood was centrifuged at $1500 \mathrm{rpm}$, the serum removed and kept at $-20^{\circ} \mathrm{C}$ until being analysed.

\section{Evaluation of the titers of peanut antiprotein antibodies}

To evaluate the titers of the peanut antiprotein antibodies, the ELISA technique was utilized. Microtitation plates were covered with $4 \mu \mathrm{g}$ of protein in $100 \mu \mathrm{L}$ of PBS per well and incubated during 12-18 hours at $4{ }^{\circ} \mathrm{C}$. Subsequently, they were rinsed twice with a $0.05 \%$ PBS-Tween solution and covered with PBS-gelatin for one hour at room temperature. The serum to be tested was diluted and incubated for 3 hours. After rinsing with PBS-Tween, goat anti- $\gamma$-chain antibody from mice was added, conjugated with peroxidase. After incubating again for 3 hours, the plates were washed and $50 \mu \mathrm{L}$ of substrate solution (ODP $-4 \mathrm{mg}, \mathrm{H}_{2} \mathrm{O}_{2}-4 \mu \mathrm{L}$ in $10 \mathrm{~mL}$ of phosphate citrate buffer) was added. The reaction was interrupted after 20 minutes with $0.1 \mathrm{M}$ of $\mathrm{H}_{2} \mathrm{SO}_{4}$ solution. The optical densities were read at $492 \mathrm{~nm}$ in an ELISA reader (Anthos 2010). The analysis of the results was performed by a comparison of the total amount of the optical densities of each serum, as denominated by ELISA*.

\section{Transplantation of heart in the auricular earlobe of mice}

Under anesthesia the animals were submitted to antisepsis using iodinated alcohol distally to the base on the ear. Subsequently, with a scalpel blade a small anterior incision was performed at the transition of the skin to the cartilage of the auricular earlobe, taking care not to injure the main auricular vessels. From the site of incision, a subcutaneous tunnel was made up the implantation site of the graft using a dissection clamp.

The newborn donor was placed in a polystyrene container with dry ice and after becoming cyanotic, was submitted to cross-sectional and lengthwise incisions in the thoracic-abdominal region and heart exposure was achieved by light compression of the animal's body. The heart was carefully removed with delicate tweezers and transferred to a Petri dish with gauze containing saline solution. Finally, the heart grafts were introduced through the tunnel under the skin of the mouse ear using tweezers. To conclude, the incision site was briefly compressed using an anatomical clamp and closure was achieved.

\section{Procurement of the transplant}

This was performed on the $15^{\text {th }}$ post-transplantation day. The animal was sacrificed by anesthesia. Immediately after the procurement, the ear was placed in an appropriate container for histology examination and submersed in Holland solution for 24 hours and was embedded in paraffin. The fixed and sectioned tissues were stained using hematoxylin-eosin (HE).

\section{Histological evaluation}

Each slide was evaluated in two occasions at an interval of one week, magnified at $100 \mathrm{x}$ and $400 \mathrm{x}$ observing the characteristics of each reading of the slides aiming at reducing the subjectivity. Each slide was read considering four parameters: nodule, peripheral infiltration, central or 
mass infiltration and granulation tissue.

- $\quad$ Nodule - Size of the specimen, that is, the size of the graft. The diameter was measured in millimeters.

- Peripheral infiltration - The intensity of the cellularity at the periphery of the grafts was subjectively measured allocating from zero to four crosses, where zero is the equivalent of no infiltration and 4 , maximal infiltration.

- Central infiltration - The intensity of the lymphocyte infiltration in the graft was also subjectively measured with zero to four crosses using the same criterion.

- granulation tissue - This parameter refers to the substitution of the graft destroyed by granulation tissue which is the most advanced and aggressive stage of rejection. This was also subjectively assessed assigning from zero to four crosses, where zero is the equivalent of the absence of granulation and 4 , to maximum granulation.

\section{Statistical evaluation}

The Tukey statistics test was used with a minimum significance of $\mathrm{p}<0.05$.

\section{RESULTS}

Clinically significant differences between the groups of each lineage were not observed, however, from immediately after the surgical transplantation procedure up to being sacrificed, the mice of the C57BI/6J lineage were more agitated and sensitive to being handed than the animals of the $\mathrm{C} 3 \mathrm{H} / \mathrm{HEJ}$ lineage.

Tolerance and immunization with peanut antigens

Figure 1 shows that the immune animals presented with significantly higher titers of anti-peanut antibodies than the normal and tolerant controls. The C57B1/6J animals that received peanut in the ad libitum diet before immunization, presented with significantly lower titers of specific peanut antibodies than those animals that were immunized and that did not eat peanuts, but without significant differences compared to the normal animals. Additionally, the C3H/HEJ animals that received peanut in the ad libitum diet before immunization, presented with significantly lower titers of specific peanut antibodies than those animals that were immunized and that did not eat peanuts. Different from the C57Bl/6J groups, there were significant differences between the tolerant animals and the normal animals.

\section{Histological evaluation}

Peripheral infiltration was always mixed, composed of polymorphonuclear, macrophage and mononuclear cells. Figure $2 \mathrm{C}$ demonstrates that $\mathrm{C} 3 \mathrm{H} / \mathrm{HEJ}$ mice from

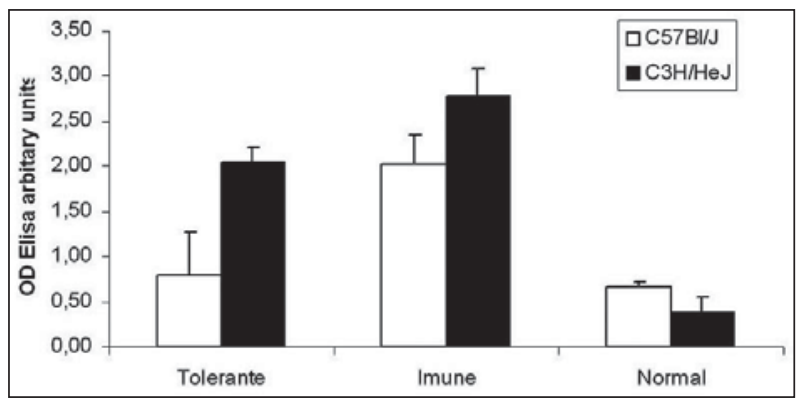

Fig. 1 - Anti-peanut antibody titers of C3H/HEJ and C57B1/6 animals after procedure of tolerance and immunization and

the tolerant group presented with a significantly lower peripheral infiltration $(p<0.001)$ than the immune and normal animals, as well as less granulation of the tissue around the graft, suggesting that the graft delayed longer to be invaded by the cells of the immune response system and, thus, the rejection process started later.

The central infiltration was less evident in the central mass of the tolerant group $\mathrm{C} 3 \mathrm{H} / \mathrm{HEJ}$ mice, indicating that the graft was protected and rejection was delayed. This finding suggests that the graft was in a better preserved stage, confirming the previous data that animals tolerant to peanuts and those that were immunized concomitant to performing the grafted with present graft protecting mechanisms.

In regard to the grafts performed in the $\mathrm{C} 57 \mathrm{~B} 1 / 6 \mathrm{~J}$ mice, Figure 3 demonstrates that the nodules of the graft and the peripheral infiltration were approximated between the tolerant, normal and immune groups, however, without being significantly different. The central infiltration was more evident, suggesting that, on the contrary to the $\mathrm{C} 3 \mathrm{H} /$ HEJ animals, the graft was not protected from the rejection process, thus not differing from immune animals. In this figure, what is different is that the normal group, without any contact with peanut immunization, presented with less granulation tissue in the graft, which demonstrates that the graft was in a more preserved stage than the other groups, suggesting that tolerance in this lineage does not have a protecting role as in the $\mathrm{C} 3 \mathrm{H} / \mathrm{HEJ}$ lineage.

In Figures 4 and 5 the granulation tissue of the $\mathrm{C} 3 \mathrm{H} /$ HEJ and C57B1/6J mice lineages was analysed. In the two lineages, the tolerant animals presented with a smaller quantity of granulation tissue than the other groups. The $\mathrm{C} 3 \mathrm{H} / \mathrm{HEJ}$ tolerant group presented with less peripheral infiltration, central infiltration and granulation tissue, whpg 
compared with the other groups of the same lineage and also in comparison with the mice of the C57B1/6J lineage. This fact certainly seems to be due to a reduced reaction to the graft in the $\mathrm{C} 3 \mathrm{H} / \mathrm{HEJ}$ tolerant group. In the $\mathrm{C} 57 \mathrm{~B} 1 / 6 \mathrm{~J}$ tolerant group, this response was expected, but was not evidenced. It is important to highlight that the granulation tissue in the tolerant animals was less than in the immune and normal groups and the central tissue was greater. The fact of having less granulation tissue, which is seen in the most advanced stage of rejection, suggests a better degree

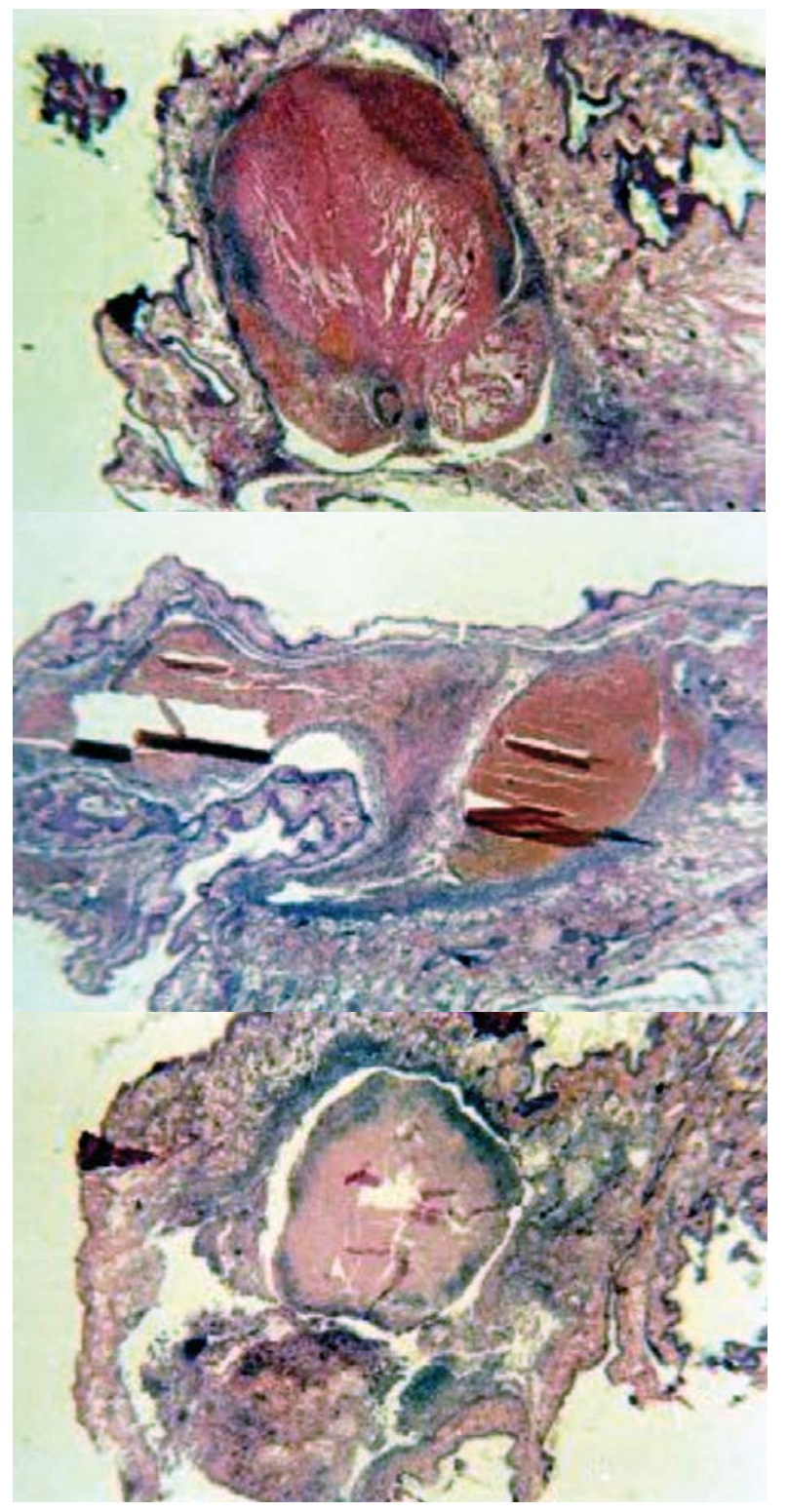

Fig.2 - Histological incision of donor heart in C3H/HEJ mice ear, tolerant $(A)$, immune $(B)$ and normal $(C)$, after 15 days of transplantation, observed with a magnification of $2.5 x$ of protection. If the specimens were obtained earlier (10-12 days), maybe this difference would be more evident.

\section{DISCUSSION}

Tissue transplantation to replace sick organs is, currently, an important medical therapy. Orthotopic heart transplantation represents a routine procedure in the treatment of terminal heart failure. Currently, three thousands transplantations are performed each year

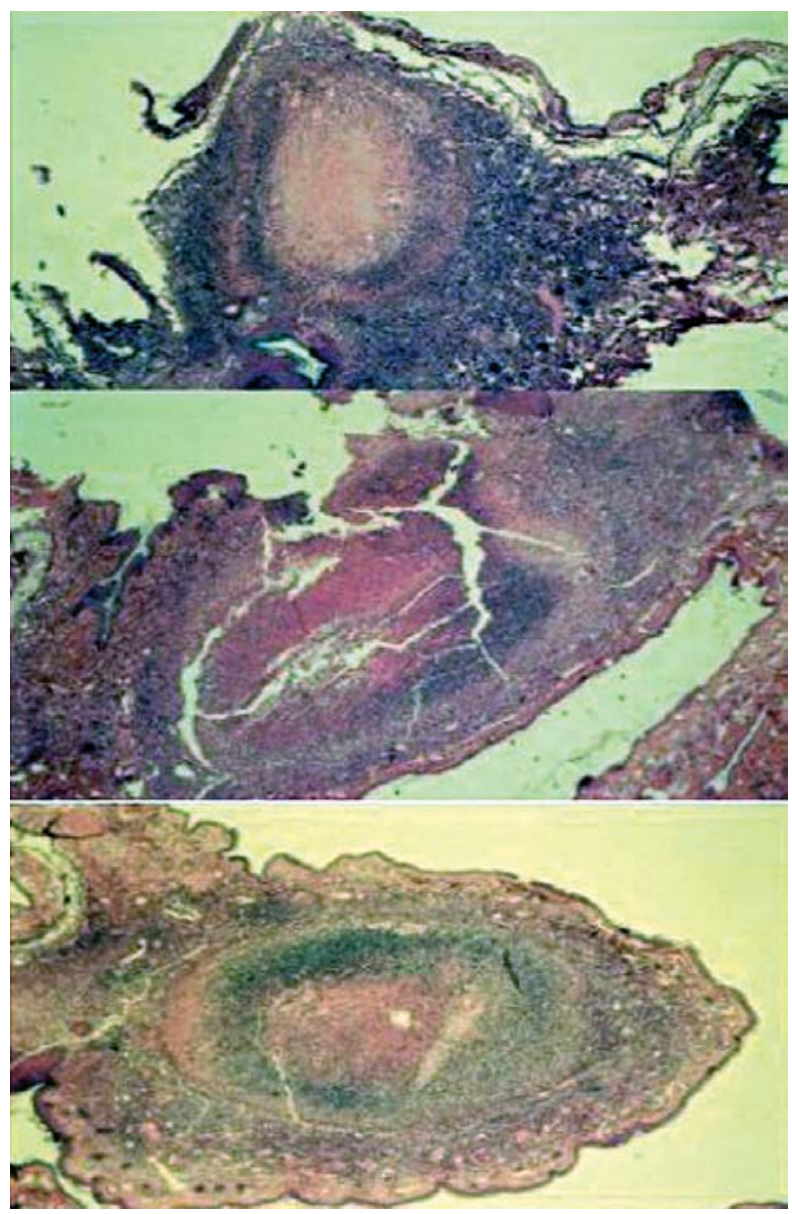

Fig. 3 - Histological section of donor heart in tolerant mice ear (a), immune (b) and normal (c), C57B1/6J, sacrificed 15 days after the transplantation magnification of $2.5 x$ 


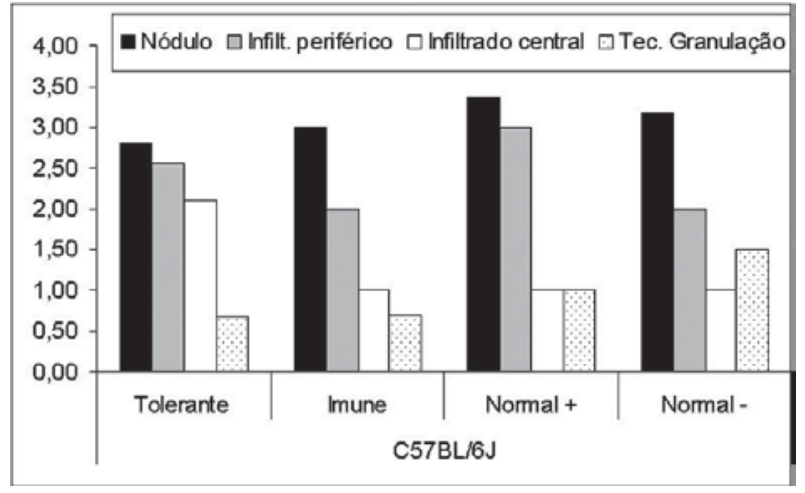

Fig. 4 - Comparison of all histological parameters evaluated after 15 days of allogeneic graft of neonatal heart $(B A L B / c)$ to the adult C57B1/6J mice ear

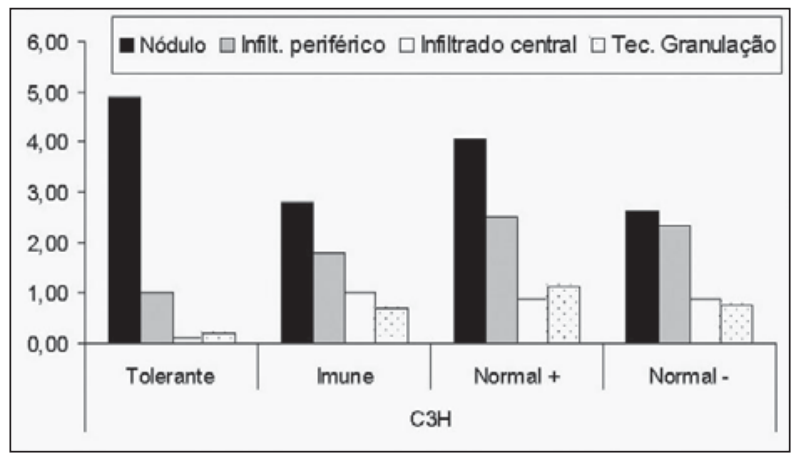

Fig. 5 - Comparison of all histological parameters evaluated after 15 days of neonatal atrial allogeneic graft $(B A L B / c)$ to the adult C3H/HEJ mice ear

around the world. The survival of the recipient after heart transplantation is around $80 \%$ over one year and $65 \%$ at five years. On average, survival has been estimated at 8.5 years and, when survival was calculated for recipients that are alive at the end of the first year, it is eleven years [23].

In this experiment, when heart allografts of mice from one lineage to another are performed, the objective is to contribute to a dream that in the future this can be performed with better survival than currently observed. Here the transplantation, rejection and tolerance are considered, all in an intelligent complex and an immunologic system that is still not well understood.

We believed tolerance to self and foreign tissues were aspects of the same basic mechanism, which consists in the direct induction of tolerance in the periphery, by deletion, anergy or immunological ignorance (in this last, the T-cells and antigens coexist without being mutually affected). Finally, there are mechanisms that involve interactions between the different types of regulatory T-cells.

Firstly, the issue is about tolerance. As the name indicates, to be tolerate is to accept or to include something as part of the self. In the immunological system, there is central tolerance that is established during the development of the lymphocytes in the central lymphoid organs during the development or maturing process and peripheral tolerance, which is acquired by mature lymphocytes in the peripheral organs. There is, also, the tolerance of antigens that enter in the organism through the mucosa. This form of tolerance is known by oral tolerance.

The objective of this study was to work with oral tolerance aiming at performing transplantations without the use of immunosuppressing drugs. From the three groups of mice, only the animals that ingested peanuts before immunization became tolerant. This was verified by measuring the antibodies by ELISA, where the smaller antibody titers were statistically significant, when compared to the other groups. This phenomenon was already clearly demonstrated in the line of research of several investigators, including Teixeira [19].

When we expanded this experiment to animals of other lineages, this phenomenon repeated if we compare animals from the same lineage that were immunized but did not have prior oral exposure. However, a significant difference in the concentration of antibodies between the lineages was observed. It is necessary to highlight that there is a difference in the antibody titers between the lineages of $\mathrm{C} 57 \mathrm{BL} / 6 \mathrm{~J}$ and $\mathrm{C} 3 \mathrm{H} / \mathrm{HEJ}$ mice and that the latter, in general, presented with higher titers of antibodies.

It is important to know if this tolerance can influence, in any way, the immunological system. So, the challenge of this work consisted in performing allogeneic avascular heart transplantations into mice ears, in the previously immunized groups and to measure the degree of rejection that the different groups presented.

In the experiment performed with mice of the C57B1/6J lineage, although there were not very great differences in the parameters of peripheral and central infiltrations, there was a difference regarding the granulation tissue suggesting a more advanced rejection stage with the tolerant group less affected. Maybe if the sacrifice of the animals had been performed on the eighth or tenth days, this difference would have been confirmed in the central and peripheral infiltrations too. We are at this stage redesigning the experiment in the attempt to answer this and other questions.

One of the explanations as to why $\mathrm{C} 3 \mathrm{H} / \mathrm{HEJ}$ mice present with higher of antibody titers to the proteins of the seeds, even in tolerant animals, may be the fact of these animals present genetical alterations (they do not present with the Toll-4 receptor, however, they do not respond to LPS 
- Lipopolysaccharide). A second explanation to the high levels of antibodies seen in these animals may be the one proposed by Caramalho et al. [24] who demonstrated that the regulatory CD4 T-cells are capable of negatively controlling inflammatory reactions stimulated by commensal bacteria and opportunist pathogens. This regulatory mechanism can occur through pro-inflammatory molecular activation of the immune system itself or directly by the bacterial products.

Caramalho et al. [24] tested the second hypothesis, that is, the hypothesis that the population of regulatory lymphocytes is activated by germinant line receptors, among which, Tolllike receptors (TLR) are one of the molecule recognizers of molecular standards, which are typical of the surface of these microorganisms. These authors demonstrated that the lymphocyte population which exerts the regulatory function, the CD45RB (low) CD25(+) T-cells, selectively express TLR-4 $-5,-7$, and -8 and when exposed to the TLR-4 ligand, the lipopolysaccharide (LPS), a positive regularization of the expression of varying cellular activation molecules occurs, as well as an increase in its proliferative capacity and of survival. This proliferation occurs independently from antigens presenting cells, but it is intensified by stimulation of the antigen receptor (TCR) and stimulation by IL-2. Another important point demonstrated by Caramalho et al. [24] is that the treatment of CD4 (+) CD25 (+) T-cells with LPS greatly increases its suppressor efficiency. This suppressing activity when tested ex vivo is not found in the CD4 (+) CD45RB (low) CD25(-) subpopulation. Another interesting finding in this group is the fact that regulatory T-cells activated with LPS efficiently control naïve T-cells in consumptive diseases. Thus, these authors demonstrated that regulatory $\mathrm{T}$ lymphocytes can be directly activated by pro-inflammatory bacterial products, thereby, contributing to the control of the inflammatory process and return of homeostasis to each tissue.

The hypothesis of this current study in relation to the $\mathrm{C} 3 \mathrm{H} / \mathrm{HEJ}$ mice is that the non-activation of the regulatory T-cell population by the absence of TLR-4 is responsible for the high levels of serum immunoglobins, both in tolerant and immune animals. The preliminary results indicate that tolerant animals present a regulation mechanism different to the classically described ones.

Immune responses are important barriers against the efficacy of tissue transplantation, destroying the foreign proteins through an adapted immune response. These responses can be mediated by cytotoxic TCD8 cells, by Th1 cells or by both.

The alloreactive effector cells, which bind directly to the Class $1 \mathrm{MHC}$ allogeneic molecules in organ transplantation, are an important cause of rejection of the graft. This is denominated direct allorecognition. Before they can cause rejection, the virgin alloreactive T-cells must be activated by antigen presenting cells (APCs) that present the allogeneic molecules and possess co-stimulatory activities.

Another mechanism of recognition of the allograft that can lead to its rejection is the capture of allogeneic proteins by antigen presenting cells and their presentation to the T-cells by molecules of the MHC itself. This is known as indirect allorecognition.

These responses can lead to rejection. As we can not suppress the response to the graft, without compromising the defenses of the host, the majority of transplanted patients require general immunosuppression, which can cause significant toxicity and increase the risk of neoplasia and infection. The fetus is a natural allograft that must be accepted and its function is almost always the survival of the species. Tolerance to the fetus can be the key to specific tolerance to grafts or it may be a special case non-applicable to organ transplantation.

In allogeneic heart transplantation, as with other organs, the HLA antigens are the main inducers of immune response against the graft. These molecules exert a fundamental role in the immune response and are responsible for the presentation of antigenic peptides to the lymphocytes.

The current concept of activation of lymphocytes is based on the model of "two signs", originally proposed by Bretscher \& Cohn [25] in relation to the synthesis of antibodies. Subsequently, this theory was adapted to the activation of T-cells. The first sign is triggered by the binding of the T-cell receptor (TCR) to the antigenic MHC-peptides complex that participate in the transduction of the first sign. The second sign or co-stimulating sign is triggered by the interaction between molecules on the surface of the APCs and their ligands on the surface of T-cells.

The T-lymphocytes are classified in two subtypes, according to the expression of the CD4 or CD8 molecules on the cell surface. Approximately $65 \%$ of the $\mathrm{T} \alpha \beta_{+}$cells express CD4 and 35\% express CD8. The responses of the TCD4+ cells are restricted to Class II MHC molecules, while the TCD8+ cells recognized antigens in the context of Class I MHC. These differentiate in cytotoxic effector cells (CTL).

Chronic rejection of the heart graft is responsible for between 23 and $30 \%$ of deaths in the first year after transplantation and is characterized by a diffuse and proliferative response of the intima of arteries to the transplanted organ. Chronic rejection seems to initiate after allorecognition of the endothelium of the graft, with subsequent infiltration of lymphocytes and production of cytokines, chemokines and growth factors. In CD4- mice or in nude mice there are no injuries of the intima of the vessels in transplanted hearts, thereby demonstrating that the CD4 cells have a capacity of promoting the rejection to the heart graft alone [26].

All these studies and discoveries show how mysterious 
and complex the defense and rejection mechanisms are. Certainly, in the tolerant group, especially in the $\mathrm{C} 3 \mathrm{H} / \mathrm{HEJ}$ mice it was possible to delay the rejection mechanism. In these mice, which were fed on peanut seed before systemic immunization, tolerance is observed. This group is the most interesting because is showed more clearly that the rejection mechanism was less intense than in the immune and normal groups. These studies show that there are several ways to block immunological responses. The experiment is simple and we are unable to say to what level the system was temporarily blocked, as there are several ways that rejection can develop. If rejection occurred by direct or indirect ways, if it were at $\mathrm{CD} 4$ or $\mathrm{CD} 8$ cell levels, we can not say, yet.

Thus, we can conclude that although total preservation of the graft did not occur, oral tolerance influenced the capacity of reacting to the external components, in this case, the allogeneic graft. In a review of the literature we did not find studies about oral tolerance. So, we concluded that our work is original, even considering the size of the experiment.

In relation to the technique, we can affirm what other authors have already reported, that it is a simple technique that can be reproduced.

\section{CONCLUSIONS}

We can conclude with this work that, although nonhomogenous, oral tolerance interferes in the rejection mechanisms of ectopic transplanted allogeneic heart in mice, suggesting an important role of regulatory T-cells in the tolerance process.

\section{REFERENCES}

1. Carrel A, Guthrie C. The transplantation of veins and organs. Am Med. 1905;10:1101.

2. Barnard CN. The operation. A human cardiac transplant: an interim report of a successful operation performed at Groote Schuur Hospital, Cape Town. S Afr Med J. 1967;41(48):12714.
3. Decourt LV, Zerbini JE. Transplante de coração humano: considerações sobre três casos. Rev Hosp Clin Fac Med São Paulo. 1970;25(4):207-26.

4. Billingham ME. Some recent advances in cardiac pathology. Hum Pathol. 1979;10(4):367-86.

5. Pomerance A, Stovin PG. Heart transplant pathology: the British experience. J Clin Pathol. 1985;38(2):146-59.

6. Mason DW, Dallman MJ, Arthur RP, Morris PJ. Mechanisms of allograft rejection: the roles of cytotoxic T-cells and delayedtype hypersensitivity. Immunol Rev. 1984;77:167-84.

7. Bishop DK, Shelby J, Eichwald EJ. Mobilization of T lymphocytes following cardiac transplantation. Evidence that CD4-positive cells are required for cytotoxic $\mathrm{T}$ lymphocyte activation, inflammatory endothelial development, graft infiltration, and acute allograft rejection. Transplantation. 1992;53(4):849-57.

8. Auchincloss Jr. H, Sultan H. Antigen processing and presentation in transplantation. Curr Opin Immunol. 1996;8(5):681-7.

9. Second International Workshop on FK 506. A potential breakthrough in immunosuppression: clinical implications. October 31, 1989, Barcelona, Spain. Proceedings. Transplant Proc. 1990;1:5-113.

10. Tsuchida M, Hirahara H, Matsumoto Y, Abo T, Eguchi S. Induction of specific unresponsiveness to cardiac allografts by short-term administration of anti-T cell receptor alpha beta antibody. Transplantation. 1994;57(2):256-62.

11. Goldstein G. Overview of the development of Orthoclone OKT3: monoclonal antibody for therapeutic use in transplantation. Transplant Proc. 1987;19(2 suppl. 1):1-6.

12. Heidecke CD, Hancock WW, Westerholt S, Sewczik T, Jakobs $\mathrm{F}$, Zantl $\mathrm{N}$ et al. Alpha/beta-T cell receptor-directed therapy in rat allograft recipients. Long-term survival of cardiac allografts after pretreatment with $\mathrm{R} 73 \mathrm{mAB}$ is associated with upregulation of Th2-type cytokines. Transplantation. 1996;61(6):948-56.

13. Binder J, Lehmann M, Graser E, Hancock WW, Watschinger $\mathrm{B}$, Onodera $\mathrm{K}$ et al. The effects of nondepleting CD4 targeted therapy in presensitized rat recipients of cardiac allografts. Transplantation. 1996;61(5):804-11.

14. Kupiec-Weglinski JW, De Sousa M. Lymphocyte traffic is modified in vivo by anti-laminin antibody. Immunology. 1991;72(2):312-3

15. Rieder I. Rejeição de transplante cardíaco alogênico em camundongos: envolvimento da laminina. In: Biologia celular e molecular. Rio de Janeiro:Instituto Oswaldo Cruz;2002. 
16. Ehrlich P. The collected papers of Paul Ehrlich. New York;1901.

17. Moog F. The lining of the small intestine. Sci Am. 1981;245(5):154-62.

18. Pappo J, Ermak TH. Uptake and translocation of fluorescent latex particles by rabbit Peyer's patch follicle epithelium: a quantitative model for $\mathrm{M}$ cell uptake. Clin Exp Immunol. 1989;76(1):144-8.

19. Teixeira GAPB. Um modelo murino de inflamação intestinal crônica tolerância e imunização oral: antigenicidade versus temporalidade. In: Patologia. Niterói:Universidade Federal Fluminense;2003. p.239.

20. Fulmer RI, Cramer AT, Liebelt RA, Liebelt AG. Transplantation of cardiac tissue into the mouse ear. Am J Anat. 1963;113:27385 .
21. Simões AP. Reprodução de um modelo experimental de enxerto de coração em orelha de camundongo. HU Revista. 1998;24:11-5.

22. Lowrey JL, Savage ND, Palliser D, Corsin-Jimenez M, Forsyth $\mathrm{LM}$, Hall $\mathrm{G}$ et al. Induction of tolerance via the respiratory mucosa. Int Arch Allergy Immunol. 1998;116(2):93-102.

23. Hosenpud JD, Bennett LE, Keck BM, Fiol B, Novick RJ. The Registry of the International Society for Heart and Lung Transplantation: Fourteenth official report-1997. J Heart Lung Transplant. 1997;16(7):691-712.

24. Caramalho I, Lopes-Carvalho T, Ostler D, Zelenay S, Haury $\mathrm{M}$, Demengeot J. Regulatory T cells selectively express tolllike receptors and are activated by lipopolysaccharide. J Exp Med. 2003;197(4):403-11.

25. Bretscher P, Cohn M. A theory of self-nonself discrimination. Science. 1970;169(950):1042-9. 